\title{
EDUCATIONAL LEADERSHIP IN AN ONLINE WORLD: CONNECTING STUDENTS TO TECHNOLOGY RESPONSIBLY, SAFELY, AND ETHICALLY
}

Mike Ribble, Ed.D.

District Director of Technology

USD 383 Manhattan/Ogden Public Schools

901 Poyntz Ave.

Manhattan, KS 66503

785-587-2066

FAX:

miker@manhattan.k12.ks.us

and

Teresa Northern Miller, Ed.D.

Associate Professor

Department of Educational Leadership

Kansas State University

Bluemont Hall 303

Manhattan, KS 66506

785-532-5609

FAX: 785-532 7304

tmiller@ksu.edu

\begin{abstract}
The current gap in technology knowledge and lack of leadership preparation related to digital literacy for school environments can cause serious problems, as school leaders, parents, and broader social communities are currently realizing. The authors describe strategies for educational leaders to prepare their stakeholder groups for a digital future, as well as take actions to reduce technology misuse or abuse. Educational institutions should consider this Digital Citizenship model as a potential new tool to for students, faculty and staff — both on-site and online.
\end{abstract}




\section{EDUCATIONAL LEADERSHIP IN AN ONLINE WORLD: CONNECTING STUDENTS TO TECHNOLOGY RESPONSIBLY, SAFELY, AND ETHICALLY}

\section{INTRODUCATION/HISTORICAL BACKGROUND}

"Just think of the possibilities we have created...we now have iPads, iPhones, Androids. We have tremendous capabilities. And....tremendous vulnerabilities. What you see is it becoming increasingly public." - General Keith Alexander (2011), Head of U.S. Cyber Command.

Technology and social networks can provide a phenomenal avenue for communication and building student/educator relationships. Students are now able to access these networks in their homes, around the corner and across the world. According to the Pew Research Center's 2011 report, Teens, Kindness and Cruelty on Social Network Sites, "Social media use has become so pervasive in the lives of American teens that having a presence on a social network site is almost synonymous with being online. Fully $95 \%$ of all teens ages $12-17$ are now online and $80 \%$ of those online teens are users of social media sites" (Lenhart et al. 2011). The rapid growth in these networks is being intensified by today's students, as the sites become a dynamic and fluid meeting place. As a result, educational leaders are increasingly being expected to become digital leaders for their school communities, as illustrated by New Jersey principal, Eric Sheninger, in a recent USA Today interview: "The Internet as we know it is the $21^{\text {st }}$ century...It is what these students have known their whole lives. They're connected, they're creating, they're discussing, they're collaborating." (Sheninger 2011) These changes in technology are causing school leaders to add new policies and guidelines for safe and appropriate use, while simultaneously working to improve their own skills in digital literacy. Karen Cator (2011), of the U.S. Department of Education, stated that educational environments need to be safe places for students. The American Library Association policy statement (2009) on digital use included a reference to school personnel's responsibility to "educate minors to participate responsibly, ethically and safely." (1)

Online education is also increasing exponentially for higher education venues (ALA Council 2009). Coursera, a start-up online education company has now enrolled 1.35 million students and will be providing more than 200 free courses across the world (Lewin 2012). The current gap in technology knowledge and lack of leadership preparation related to digital literacy for school environments can cause serious problems, as school leaders, parents, and broader social communities are currently realizing. How are educational leaders to prepare their students for a digital future when they do not yet fully understand these technologies?

While technologies such as online social networks do provide a place to explore and express ideas across all social lines, the same tools that can provide opportunities can also be used to victimize users. The devastating effects of technology misuse for young adults who have been marginalized by society are being played out in the media at an ever-increasing rate. Activities in the past three years include the suicide by a Rutgers University student, as well as students in Ohio, Missouri, and Oregon (Hampson et al. 2010). The Pew Research Center's 2011 report, Teens, Kindness and Cruelty on Social Network Sites, indicates that $25 \%$ of the respondents said that an interaction on a social media site led to a face-to-face argument, 22\% said that it ended a friendship, and 13\% reported that it made them nervous to attend school the next day (Lenhart et al. 2011). These events place a spotlight on the issues that surround technology use and misuse. It also should be a warning for educational leaders that they now need to address responsible technology use. 
The need to help educators begin to address specific technology and citizenship issues, such as cyberbullying (and other technology misuse), has become a focus for educational leaders. Many antibullying programs and tools are available but with little direction, instruction or follow-up, and these programs often have less than favorable results. Technology users of all ages are now reaping the benefits, as well as the problems, that go along with more than a decade of rapidly increasing technology advances, without direction about appropriate use. Educational leaders have a responsibility as protectors of students, and as such can become part of the problem, if they do not take proactive steps to begin finding solutions to cyberbullying and other technological issues.

With increased use and interest in online technologies, the bullying potential has grown exponentially, by providing multiple opportunities for cyberbullying. Students perceived as different from what others consider the "mainstream" have always been targets for bullying. In the past, bullying of marginalized groups was limited to one-on-one or smaller groups. Now that the technology removes the need to come face-to-face with one's victims, those who may not have acted on bullying tendencies in the past may feel more able to participate in bullying. In Ivester's book LOL OMG (2011), it is obvious that the issues of cyberbullying are not limited to school yard "toughs." Now, with the ease of access and speed of connectivity, almost anyone can violate what is considered appropriate in the online world. To address this problem, all educators need to expand their views, as well as school policies, related to what is considered "inappropriate" technology use, focusing on the actions and not the individuals.

Technology is changing responsibilities of all those involved, including school leaders, as illustrated in California. Bill AB 746 gave California school administrators the ability to suspend or recommend expulsion when social networks were used for cyberbullying (Converge 2011). As school leaders become legally responsible for dealing with the issues related to the misuse and abuse of technology in their schools and with their students, they must determine how best to address these issues as they occur.

Educators need to reach out to all members of the community for assistance. The problem is that many do not understand, or do not want to learn about the issues related to technology use and misuse. Sabella (2010), former president of the American Counselor Association, stated that parents "are not taking the time and effort to educate themselves, and as a result, they have made it the responsibility of the schools. But the schools didn't give the kids their cell phones." (2) As a result of non-action by parents and other members of the community, K-20 schools become the gatekeepers and must educate students, parents and community members about these skills. As technology use increases, the school-related issues also increase. One key issue is the lack of understanding related to training students, staff, and faculty members in the appropriate use and etiquette for social media and ways to avoid or stop cyberbullying. A second issue that is continuing to grow is how technology has begun to affect students in other aspects of their lives as well (e.g., health, safety, and respect for others).

A concern related to technology misuse is the lack of empathy that students are showing towards each other. In a University of Michigan Institute of Social Research study (O'Brien et al. 2010), the amount of empathy in college students was analyzed for over 14,000 students over the last 30 years. Their results showed that current students surveyed were 40 percent less empathetic than survey results from 1979, and suggested that the lack of emotional connection in social networking sites may be partly to blame. Increased exposure to media content ( three times more than in the past) was mentioned, and the increase of violent media that "numbs people to the pain of others" (p. 2). In addition, the lack of face-to-face interaction can serve to dehumanize the other person, adding to this lack of emotional connection.

In a Rutgers University example, other students took video and posted a sexual encounter without considering the effect on the student or possible consequences for the behavior itself. Increases in reports of K-12 cyberbullying incidents also indicate this lack of empathy. This type of behavior must not just be written off as 'kids being kids.' The audience that students have today is much larger than in the past and they have the ability to connect with this audience immediately. It is imperative that educational leaders 
access and utilize all the positive aspects of the new technologies as they also find ways to reduce or eliminate the negative facets of these tools, for all students. Ignoring the problem is not an option. The time is now to act quickly and responsibly to address the issues of cyberbullying and personal responsibility.

To address the potential cyberbullying, as well as other technology issues, educational leaders need to guide students, faculty and staff in recognizing their own responsibility, and in developing empathy and understanding for others. As students are thrust into an odd combination of RL (Real Life) and OL (Online Life), they can often have hundreds of "friends" that they never meet (Ohler 2010). Students are using tools created for adults, which requires them to become more mature in their interpersonal skills of how to balance their OL interactions with those in RL. Students need to put a "face" to their postings, and realize that they are interacting with real people, not just inanimate laptops or smart phones. All users need to regain some of that empathy and etiquette for others, to think about others and their needs, as well as their own. Times and technologies have changed, but the need for basic skills in humanity are important no matter how people connect with others. Today's students live in a highly technical world with increasing online communications options while having fewer visual cues available. School leaders must find ways to enhance relationship-building, using technology, for themselves, their faculty members, and for their students. As a sample response to this problem, Rutgers University is conducting a two-year dialogue focused on civility and helping those in the community "get along and interact" (Hampson et al. 2010, 2).

\section{MOVING FORWARD - DIGITAL CITIZENSHIP}

How can schooleducational leaders help provide the skills necessary for their students and staff? Technology provided without direction or instruction has the potential to cause issues with others. In the past, there has been an inability to hold individuals accountable for their actions related to inappropriate use of technology, or to set any standards for appropriate use. In 2009, The International Society for Technology in Education (ISTE) provided such guidance by updating the National Education Technology Standards (NETS) for educational leaders, teachers, and students. Widely adopted and recognized in the United States, and increasingly adopted in countries worldwide, the NETS integrated educational technology standards across all educational curricula. Now with this basic set of skills, steps need to be taken to implement these standards in daily practice in schools.

In 2011, Ribble's second edition of Digital Citizenship in Schools was released through ISTE and focused on the attributes required for digital citizens. Nine elemental areas were identified that ultimately define those living in a digital society, organized under three general headings: Respect - Educate - Protect, or REP. The three categories and nine areas are listed below, with suggestions for educational leaders on implementation, are followed by examples from schools currently using these methods.

\section{Respect Your Self/Respect Others}

- Digital Etiquette. Starting at a young age, educational leaders need to begin make parallels for students between being good to each other both in the classroom and in the digital world. Users need to be provided with specific examples of appropriate action in both worlds.

- Digital Access. Work within educational institutions needs to focus on all students having similar digital opportunities. Efforts should be made and monitored to ensure that all groups have access to technology and if there is not, access accommodations need to be made.

- Digital Law. As in Real Life (RL), if something is taken which has value, it is stealing. Students need to see the connection between RL (Real Life) and OL (Online Life) and understand that those basic laws apply to the OL, as well as the RL.

As examples of implementation policies, several states have taken steps toward prevention of cyberbullying by passing cyberbullying laws for schools--Arkansas, Idaho, Iowa, Missouri, New Jersey, 
New York, Oregon, , Rhode Island, and Vermont (El Rahman 2010). New York's State Senate passed the Dignity for All Students Act (2011) "to protect public school students from extreme and constant bullying" (Oluwa 2010, paragraph 6). Additional policies in progress in New York are to ban cyberbullying and sexting, and to require annual instruction for staff and students on bullying prevention. Educate Your Self/Connect with Others

- Digital Communication. Discussions should be held with students on which situations require which technologies (or media) for interpersonal interactions. Students need to have an understanding of how to be clear to avoid misunderstandings when there is no way to see reactions, facial expressions, etc.

- Digital Literacy. As the numbers of digital tools grow, there is a need to expand on knowledge of the basics that can be applied to several technologies. The basic technology skills of the past 10 years (e.g. understanding various word processing packages) are disappearing and being replaced by very specific new literacy skills (e.g. social networking, texting).

- Digital Commerce. Students need to know how to protect themselves and their information in an online world. Students need to know which sites are safe, how much information to share, and how to protect their financial reputations.

\section{Protect Your Self/Protect Others}

-Digital Rights and Responsibility. Educational leaders need to reinforce that the access students have online requires following the rules, or the students' rights can be revoked. Students need to realize that when they feel uncomfortable in a situation, they need to report it to someone in authority.

- Digital Safety (Security). Educational leaders need to ensure that technology tools and information are protected. Students need to also become aware that even not doing something (e.g. keeping virus protection up to date) can have an impact on themselves as well as others.

- Digital Health and Welfare. Educational leaders need to understand the need for, and how to, set limits of technology use as a necessary skill for all users. Students need to understand that limits must be set to live a balanced life between OL and RL.

Table 1 summarizes Ribble's three categories and nine elements of the Digital Citizenship model.

Respect Yourself/Respect Others

- Digital Etiquette: electronic standards of conduct or procedure.

- Digital Access: full electronic participation in society.

- Digital Law: electronic responsibility for actions and deeds

Educate Yourself/Educate Others

- Digital Communication: electronic exchange of information.

- Digital Literacy: process of teaching and learning about technology and the use of technology.

- Digital Commerce: electronic buying and selling of goods.

Protect Yourself/Protect Others

-Digital Rights and Responsibility: those freedoms extended to everyone in a digital world.

- Digital Security: electronic precautions to guarantee safety.

- Digital Health and Welfare: physical and psychological well-being in a digital technology world. 
Digital citizenship is a growing topic and concern for school leaders. In Pike County, Kentucky, educational leaders have committed an entire month in the fall $(2009,2010)$ for updating knowledge, creating projects, and sharing of ideas for appropriate technology use. After working with these skills for the past two years staff, parents and students now understand the nine elements, which has benefited them with fewer incidents of digital technology misuse in their schools. The Osseo, Minnesota, district has begun the process of expanding the teaching of digital citizenship to primary students. Their program is tied to their C4 model of staff development and aligned to ISTE's National Educational Technology Standards (2009). The C4 Model of Learning_is a professional development program that equips teachers to combine collaboration, creativity, and communication to create transformative content. Sponsored by Osseo (MN) Area Schools, the C4's overarching goal is to develop a mindset that recognizes the dynamic and integral connection between teaching, content knowledge, and technology. The teaching of digital citizenship concepts has also been growing internationally, as exemplified by the Department of Education and Community of New South Wales, Australia. They have committed time and resources to create curriculum for students, ages 5-16, specifically related to digital citizenship skills. Web-based information and staff development sessions for teachers and staff have already been created.

As expressed in the three main categories and the nine areas, a need exists to not only be aware of one's own technology use, but that of others, which links the knowledge of these categories to developing empathy. Each of the nine areas requires technology users to think about what they are doing currently with a technology, but also asks them to stop and think about others as they interact online. The focus of the categories, Respect, Educate, and Protect, is to encourage users to focus as much on others' use as themselves. This focus can help move students from concepts of empathy to personal responsibility and recognition of potential impact within their interactions. In Teaching Empathy: A Blueprint for Caring, Compassion, and Community, Levine (2005) stated that to teach empathy, educators needed a combination of social skills which include high-levels of listening, perspective-taking, decision-making, and helping others. Levine's list reinforced the elements and categories of Digital Citizenship stated previously and can be as applicable in the OL world as in RL.

All technology users need to begin a process of understanding basic skills of technological literacy starting at a very young age. Students today are coming to school with a wide-ranging set of technology skills that are beginning to change how teachers are teaching, as well as when and how students learn. However, many students are using technology without awareness of technology use etiquette and/or Digital Citizenship requirements. The Online Safety and Technology Working Group (OSTWG) in its 2010 report, Youth Safety on a Living Internet, submitted its recommendations for the promotion of digital citizenship elements in Pre-K-12 education as a national priority. The report stated that educators "in the process of teaching regular subjects, teach the constructive, mindful use of social media enabled by digital citizenship and new-media-literacy training" (p. 20). These skills need to be presented in an organized manner to help students understand the connection between these elements. As the likelihood of a multi-generational work force in schools increases, training in digital citizenship will be needed for all groups - faculty members, students, and community members.

As noted in the Pew study on social media (Lenhart et al. 2010), "the internet is a central and indispensable element in the lives of American teens and young adults" (p. 5). It is imperative that school leaders act responsibly to provide digital age leadership and embed digital citizenship elements into all aspects of teaching and learning. These skills will be needed to protect all members of their communities from inappropriate use of technology. Educational leaders must make sure that they are modeling digital citizenship, that students within their schools are safe, and that students learn the skills to live and thrive in a digital world. By providing this knowledge and modeling these skills, leaders can ensure that issues such as cyberbullying will diminish. As technology continues to become a more integral part of students' lives, making sure that all members within school environments are well versed in appropriate use and digital citizenship will be an imperative. 
School leaders must become aware and begin addressing these needs for their students if the major thrust of education is to prepare children to become responsible adults. According to Stone (2011), social networks are "becoming the gravitational centers of the digital universe" (p. 60). Since June 28, 2011, ten million users have signed up for the new Google+ social network! (p. 60) If educational leaders wish to curtail the problems of cyberbullying and develop students with empathy and a sense of personal responsibility, students who can become strong, positive digital citizens, changes must occur now to address the technology issues.

\section{NEXT STEPS-CHANGES IN EDUCATION}

All levels of educators are beginning to realize that the technology revolution has caused them to reevaluate policies and procedures within their organizations. Sites like Facebook and Twitter were created as tools to communicate socially and are now being used to share information in and about classrooms. With these intrusions into the classroom, the line between social and educational use are becoming blurred. As an example, should the comments about an educator mentioned on a social networking site become the topic for everyone? Too often users forget that what they are sharing may not always be a private conversation between individuals (Ivester, 2011), but may be viewed by many others, including those whom the 'private' conversation was about!

With the growth of social networking, students can forget that even on educational sites like Blackboard and MyBigCampus, how and what they post is different than Facebook. To this end, schools are beginning to move to a code of conduct that users can begin to differentiate what information can and should be shared in what venue. Many K-12 districts are integrating digital citizenship training as part of their school improvement efforts. Changes in federal funding are causing changes that require schools receiving E-Rate (technology school funding) to begin teaching about appropriate technology use. Although slower to make changes in policies and procedures for technology use, schools and colleges of education have brought growth in this discussion as they prepare educators. Pre-service students are learning about setting policies on how students will use technology in their schools. Some preparation programs are focusing on ethical use and what not to do as opposed to educating about the issues and where and where certain activities are appropriate.

For many educators this is a frustrating time as not only is the technology use changing within the classroom, but so are the standards for education. These may seem to be different topics but they are pointing to the same end: better educational opportunities for students. Educators need to look at these changes as opportunities to bring the concepts of technology and educational theory together. As the United States, Australia and Canada begin to implement new educational standards, it is the time to begin connecting the changing tools of education to merge with these standards. By looking at a number of the Sloan-C Student Support Items from the Sloan-C Quality Scorecard, the WCET's Spider Web Suites, and the elements of Digital Citizenship (Table 2), it becomes very clear that what is occurring within online education has a direct correlation to how all students, K-12 and in higher education, should be using technology appropriately. 


\begin{tabular}{|c|c|c|}
\hline $\begin{array}{l}\text { Sloan-C Student Support Items } \\
\text { from the Sloan-C Quality Scorecard }\end{array}$ & WCET's Spider Web Suites & Digital Citizenship \\
\hline $\begin{array}{l}\text { Throughout the duration of the } \\
\text { course/program, students have access to } \\
\text { appropriate technical assistance and technical } \\
\text { support staff. }\end{array}$ & $\begin{array}{l}\text { Academic Services Suite } \\
\text { (Technical Support) }\end{array}$ & $\begin{array}{l}\text { Digital Rights and } \\
\text { Responsibilities }\end{array}$ \\
\hline $\begin{array}{l}\text { Student support personnel are available to } \\
\text { address student questions, problems, bug } \\
\text { reporting and complaints. }\end{array}$ & $\begin{array}{l}\text { Academic Services Suite } \\
\text { (Technical Support) }\end{array}$ & $\begin{array}{l}\text { Digital Rights and } \\
\text { Responsibilities }\end{array}$ \\
\hline $\begin{array}{l}\text { Minimum technology standards are } \\
\text { established and made available to students. }\end{array}$ & $\begin{array}{l}\text { Personal Services Suite } \\
\text { (Orientation) Academic } \\
\text { Services Suite (Technical } \\
\text { Support) }\end{array}$ & Digital Literacy \\
\hline $\begin{array}{l}\text { Policies and process are in place to support } \\
\text { ADA requirements. }\end{array}$ & $\begin{array}{l}\text { Academic Services Suite } \\
\text { (Disability Services, Technical } \\
\text { Support) }\end{array}$ & Digital Access \\
\hline $\begin{array}{l}\text { Efforts are made to engage student with the } \\
\text { program and institution. }\end{array}$ & $\begin{array}{l}\text { Communications Suite (all } \\
\text { services including social media } \\
\text { and emerging technologies) }\end{array}$ & $\begin{array}{l}\text { Digital } \\
\text { Communication }\end{array}$ \\
\hline $\begin{array}{l}\text { Students are instructed in the appropriate } \\
\text { ways of communicating with faculty and } \\
\text { students. }\end{array}$ & $\begin{array}{l}\text { Personal Services Suite } \\
\text { (Orientation) Communications } \\
\text { Suite }\end{array}$ & $\begin{array}{l}\text { Digital } \\
\text { Communication }\end{array}$ \\
\hline $\begin{array}{l}\text { The institution provides guidance to both } \\
\text { students and faculty in the use of all forms of } \\
\text { technologies used for course delivery. }\end{array}$ & $\begin{array}{l}\text { Distance Learning \& } \\
\text { Information Technology } \\
\text { Departments }\end{array}$ & Digital Literacy \\
\hline $\begin{array}{l}\text { Students are instructed in the appropriate } \\
\text { ways of enlisting help from the program. }\end{array}$ & $\begin{array}{l}\text { Personal Services Suite } \\
\text { (Orientation) Academic } \\
\text { Services (Academic Advising) }\end{array}$ & $\begin{array}{l}\text { Digital Rights and } \\
\text { Responsibilities }\end{array}$ \\
\hline
\end{tabular}

Tanle 2, Sloan-C Student Support Items, the WCET's Spider Web Suites and the elements of Digital Citizenship

While technology has become an important aspect to all education, the pedagogy must not be lost. As Fullan (2013) has identified in his book Stratosphere, technology can make education more efficient, but it cannot be a replacement for good teaching. As educators learn more about technology, they need to see it as a tool for helping to support and extend the learning experience. The nine elements of the Digital Citizenship model should be considered as a potential method to be added to the array of services offered to K-12 and college students - both on-site and online. Technology is not the answer to the issues within education, but it can provide avenues to begin addressing them. While this is being done, educators, students, and staff need to understand how to use technology in appropriate ways.

Educational leaders are now placed in the awkward position of playing 'catch up' as they determine how to address issues of technology use and abuse. Educational leaders, faculty members, students, parents, 
and community members must work together to create workable solutions for the rapidly increasing problems related to appropriate use and digital citizenship. It is the responsibility of educational leaders to prepare students not just for today, but to become positive contributors to society, which now includes a large digital component.

\section{REFERENCES}

1. ALA Council. Minors and internet interactivity: An interpretation of the Library Bill of Rights. 2009. http://www.ala.org.

2. Alexander, K. In: Rose, "C. Charlie Rose talks to General Keith Alexander." Bloomberg Businessweek (July 25-July 31, 2011), 36.

3. Cator, K., In: Toppo, G. "Making students literate in digital age." USA Today (July 25, 2011), 2 A.

4. Converge. California clarifies cyberbullying law to include social networks, 2011.

5. Retrieved from http://www.convergemag.com/policy/California-Clarifies-Cyberbullying-Law. html?elq=50482b36f26543858d lebc2437dedafa

6. El Rahmen, M. "Cyberbullying: A rundown of cyberbullying laws." Law \& Daily Life, (January 27, 2010). Retrieved from http://blogs.findlaw.com/law_and_life/2010/01/cyberbullying-suicideshows-need-for-cyberbullying-laws.html

7. Fullan, M. Stratosphere: Integrating technology, pedagogy, and change knowledge. Toronto, Canada: Pearson Canada, Inc., 2013

8. Hampson, R., Leinwand, \& Marcus, M.B. "Has social networking gone too far?" USA Today (October 1-3, 2010), 1-2.

9. Ito, M., Horst, H., Bittanti, M., et al. Living and learning with new media: Summary of findings from the digital youth project. MIT Press, Cambridge, MA, 2009.

10. Ivester, M. Lol, omg. Reno, NV: Serra Knight Publishing, 2011.

11. Lenhart, A., Purcell, K., Smith, A. \& Zickuhr, K. Social media \& mobile internet use among teens and young adults. Pew Internet and America Life Project, Washington, D. C. 2010. Retrieved from http://pewinternet.org/Reports/2010/Social-Media-and-Young-Adults.aspx

12. Lenhart, A., Madden, M., Purcell, K., Rainie, L. Smith, A. \& Zickuhr, K. Teens, kindness and cruelty on social network sites. Pew Internet and America Life Project, Washington, D. C. 2011. http://www.pewinternet.org/Reports/2011/Teens-and-social-media.aspx

13. Levine, D. Teaching empathy: A blueprint for caring, compassion, and community. Solution Tree, Indiana, 2005.

14. Lewin, T. Education site expands slate of universities and courses. New York Times, (September 19, 2012), A20.

15. National Educational Technology Standards for Administrators, Teachers, Students. ISTE, Portland, OR, 2009. Retrieved from http://www.iste.org/nets

16. O'Brien, E.H., Hsing, C., \& Konrath, S. Changes in dispositional empathy over time in American college students: A meta-analysis. University of Michigan Department of Psychology, Minnesota, 2010.

17. Ohler, J.B. Digital community, digital citizen. Corwin Press, CA, 2010.

18. Oluwa, R. "Bedford schools approve cyberbullying policy." Bedford-Katonah Patch (June 25, 2010). Retrieved from http://bedford.patch.com/articles/bedford-schools-approve-cyberbullyingpolicy

19. OSTWG. Youth safety on a living internet: Report of the online safety and technology working group. Online Safety and Technology Working Group, Washington, D.C., 2010. Retrieved from http://www.ntia.doc.gov/advisory/onlinesafety/

20. Ribble, M. Digital citizenship in schools. ISTE, Oregon, 2010.

21. Sabella, R. In: Hoffman, J. (2010). “As bullies go digital, parents play catch-up.” New York Times (December 4, 2010). Retrieved from http://www.nytimes.com/2010/12/05/us/05bully.html

22. Sheninger, E. In: Toppo, G. "Making students literate in digital age." USA Today (July 25, 2011), 2A.

23. Stone, B. “Circle logic.” Bloomberg Businessweek (July 25-July 31, 2011), 58-61. 


\section{ACKNOWLEDGEMENTS}

School Resources:

- Pike County, Kentucky, School District

- Osseo, Minnesota School District

- Department of Education and Community, New South Wales, Australia 